\title{
International Initiatives
}

By Andreas Hübner, Helmholtz Association of German Research Centres

A large number of international Open Access initiatives strive for the implementation of the idea of Open Access. A few of the most important ones are introduced below.

\section{WSIS (World Summit on the Information Society)}

After the Internet became a mass medium during the 1990s and the relevance of 'information as a raw material' within the global society became more and more clear, politicians increasingly had to address the question of a global framework for the information society. Following some (trans)national initiatives, this resulted in the idea of a 'World Summit on the Information Society', which was taken up by the UN in 2001. The summit was held in two phases as part of the implementation of the UN Millennium Declaration: in Geneva in 2003, and in Tunis in 2005. One of the summit's special features was the participation not just of governments but of all involved stakeholders, i.e. business representatives and civil society.

The Declaration of Principles and the Plan of Action passed in Geneva after some tough wrangling about wording are not binding under international law, but were rather formulated as an appeal. Amongst other things, they refer to improved access to information. Unlike the (sometimes very advanced) debate on Open Access in developed countries, the documents passed by the summit also focus on measures to overcome the global digital divide, in other words they also focus on the development of basic technologies and infrastructure in the world's less developed regions as a prerequisite for Open Access to information. The Declaration of Principles states with regard to Open Access: "We strive to promote universal access with equal opportunities for all to scientific knowledge and the creation and dissemination of scientific and technical information, including Open Access initiatives for scientific publishing'(124).

The Plan of Action is intended to guarantee the concrete implementation of the visions and tenets formulated in the Declaration of Principles by 2015. One of the plan's eleven central points of action is entitled 'Access to Information and Knowledge' and formulates recommendations for governments and others, in order to achieve improved access to information. One of the measures the Plan of Action states in this regards is the following: 'Encourage initiatives to facilitate access, including free and affordable access to Open Access journals and books, and open archives for scientific information'(125). In order to implement the different 
courses of action, first consultation meetings were held in October 2006, where UNESCO was confirmed as an official facilitator for the areas 'Access to Information and Knowledge' and 'E-science', amongst others. At the same time working topics were developed.

The documents passed by WSIS in Geneva are the lowest common denominator to which the UN's 192 Member States could agree. As a result, they are carefully formulated and concerned with balancing interests, not least when it comes to Open Access. This was particularly criticized by representatives of civil society, causing them to formulate their own final document, which speaks more clearly and sees itself as an important supplement to the official documents. The documents passed by WSIS in Tunis (Tunis Commitment and Tunis Agenda for the Information Society) do not go any further than the documents passed in Geneva with regard to Open Access, but they do expressly confirm them.

\section{OECD /Organisation for Economic Cooperation and Development) $\bullet \bullet \bullet \bullet \bullet \bullet \bullet$}

In contrast to the documents passed by WSIS, which take a more comprehensive look at the world's less developed regions, the OECD, as the coordinating committee of the 30 leading developed countries in the area of economic policy, is mainly concerned with the impact of Open Access on economics and research policy.

In January 2004, a Declaration on access to publicly funded research data was passed. In addition to the OECD states, China, Israel, the Russian Federation, and South Africa also signed the document. Amongst other things, they acknowledge their commitment to the principles of balance, transparency, good scientific and scholarly practice, and the observation of quality and security standards. In this spirit, the OECD Council's recommendation regarding access to publicly funded research data was published in December 2006. This document expresses a clear recommendation for the signatory states to legislate towards Open Access. In addition, the OECD Council seeks to monitor the implementation of the recommendation in the individual states and to adapt the guidelines to new developments in technology and scientific practice if need be.

Besides Open Access to data, the OECD also adopted a position with regard to Open Access in the entire area of publicly funded scientific and scholarly publishing. A report was published in September 2005, which provides 
detailed descriptions of economic structures and added-value chains, as well as of existing and new business models based on online access. It concludes with 'Challenges and Policy Considerations'. This report, like the declaration on the subject of research data (see above), recommends maximum access to research results in order to obtain greater social benefit.

While the OECD has made a statement on Open Access to research data in the binding form of a declaration whose implementation is to be monitored, Open Access to general research results has so far only been recommended in the above-mentioned report.

\section{IFLA (International Federation of Library Associations and Institutions)}

Founded in 1927, IFLA sees itself as the leading global representation of libraries and information services. IFLA feels committed to the principle of Open Access, particularly with regard to access to academic literature in developing countries. In the past few years, several declarations on Open Access have been passed, such as the 'IFLA Statement on Open
Access to Scholarly Literature and Research Documentation' (February 2004). This statement states IFLA's support of the principles underlying Open Access, including the defence of authors' rights, opposition to any kind of censorship, affordable access for individuals in developing countries, and the support of sustainable Open Access publication models.

In 1997, IFLA set up the committee on 'Free Access to Information and Freedom of Expression'. This committee deals with article 19 of the United Nations Universal Declaration of Human Rights in so far as it is relevant to libraries. With regard to freedom of opinion, this article demands that everyone should be able to seek, receive and impart information and ideas regardless of frontiers. Important IFLA FAIFE documents include the 'IFLA Internet Manifesto' (May 2002) and the 'IFLA/UNESCO Internet Manifesto Guidelines' (September 2006). Amongst other things, the Internet Manifesto calls upon the international community and national governments to promote the development of information structures and worldwide Internet access. The guidelines mainly address libraries and go into some detail inter alia regarding programmes for Internet access as well as the development of services in libraries in order to make strategy decisions in these areas easier. 


\section{UNESCO (United Nations Educational, Scientific and Cultural Organisation) $\cdots \cdots \bullet$}

UNESCO supports the creation of Knowledge Societies in which everyone has access to information and knowledge. It places its emphasis on education and development and includes ethical, social and political perspectives.

The UNESCO Recommendation concerning the Promotion and Use of Multilingualism and Universal Access to Cyberspace, which was passed in autumn 2003, calls for the promotion of Open Access solutions: 'Member States and international organisations should encourage Open Access solutions including the formulation of technical and methodological standards for information exchange, portability and interoperability, as well as online accessibility of public domain information on global information networks'(126). Member States report back every four years on their implementation of this 'Cyberspace Recommendation'.

UNESCO is significantly involved in the process of the 'World Summit on the Information Society' and plays an important role in the implementation of the Geneva Plan of Action. For one, it has been named an official facilitator of the Action Lines 'Access to Information and Knowledge' and 'E-science'. In addition, UNESCO is working with many other initiatives in the area of access to information and knowledge, where it takes on a supporting and facilitating role, as for example with the formulation of the IFLAVUNESCO Internet Manifesto Guidelines. They state that 'unhindered access to information is essential to freedom, equality, global understanding and peace'(127).

\section{SPARC IScholarly Publishing and Academic Resources Coalition) 0000000000000}

SPARC was founded in 1998 with its seat in Washington DC (USA) as an international alliance of university and research libraries. Originally concerned with increasing competition in the publications market with the goal of lowering journal prices, SPARC has now become an important international action platform, which is developing new communication models for academic publishing in cooperation with other initiatives and partners and is committed to Open Access. More than 220 mainly North American libraries are members of SPARC (as of January 2007). In addition, several large library organisations from all

126 http://portal.unesco.org/en/ev.php-URL_ID=17717\&URL_DO=DO_TOPIC\&URL_SECTION=201.html. paragraph 18.

127 http://www.ifla.org/faife/policy/iflastat/Internet-ManifestoGuidelines.pdf. 
around the world are associated members. SPARC Europe was founded in 2001 as an independent spin-off of SPARC and currently has more than 100 members. These are also associated, as are the more than 600 libraries of SPARC Japan, which started work officially in December 2006. SPARC provides information on authors' rights (development of an addendum to authors' contracts), supports openly accessible and inexpensive journals (Publisher Partner Program), and offers strategic and practical advice for publishers who wish to get involved in Open Access publishing (Publisher Assistance Program). SPARC is supported by US-lobby groups such as the Open Access Working Group (OAWG) and the Alliance for Taxpayer Access (ATA) and thus plays an important role in the political arena, particularly in the United States. 